\title{
Exploring the Relationship Between Human Resource Practice, Organisational Support, Social Support, Performance and Intention to Leave of Teachers
}

\author{
Petro Van Der Merwe
}

Unisa, Pretoria, South Africa,

Email:vdmerp1@unisa.ac.za

Elsabé Keyser

North-West University, Vaal Triangle Campus, South Africa,

Email: elsabe.keyser@nwu.ac.za

Doi:10.5901/mjss.2014.v5n13p93

\begin{abstract}
This research was conducted to examine the relationship between human resource practice, organisational support, social support, performance and intention to leave of teachers in South Africa. Three hundred teachers at different schools were invited to participate in this research. Using a quantitative research approach, six standardised questionnaires, including a Biographical Questionnaire, a Human Resource Practice Scale, Organisational Support Scale, Social Support Scale, Performance Scale and Intention to Leave Scale were used. The findings revealed that a positive practical significant relationship with a medium effect exists between human resource practices, organisational support and intention to leave, but a negative practical significant relationship exists between human resource practices and intention to leave of teachers. Furthermore, a positive practical significant relationship with large effect was found between organisational support and social support, but a negative practical significant relationship with a medium effect exists between organisational support and intention to leave.
\end{abstract}

Keywords: teachers, human resource practice, organisational support, social support, performance, intention to leave

\section{Introduction}

A school where the values and focus of the school management centre around enhancing the pupils' knowledge and life skills, where the staff members accept, support and encourage one another, and where the principal is leading and protecting his/her teachers and managing the school as a well-oiled machine, is a challenging issue for teachers, school principals and governing bodies, and has also attracted the attention of researchers. School management/support, in its broadest sense, is defined as a satisfactory level of involvement or "fit" between the governing body, school principal and teachers. If teachers know that their principal is supporting and protecting them, they have more courage and more selfconfidence in executing their task.

This study is an attempt to contribute afresh with a new perspective to the field of human resources and behavioural sciences, with specific reference to organisational and social support in school systems. A school should maintain its multi-functional purpose. Teachers are not only in the teaching profession because of their knowledge of the subject - they are subject specialists, educators, psychologists, parents, and examples for the pupils who sit in front of them. If teachers are being viewed as multi-tools, the principal and the school system should be a pocket in which the multi-tools are stored. This study has challenged the participating teachers to reflect on their own teaching praxis experience, and the school support systems and their influence on their performance.

Teachers often expressed their lack of confidence in the organisational and social support system. A scoping study that was carried out to test the initial research framework presented preliminary evidence that teacher's experience that nobody is willing to give them constructive critique or support (Jansen \& Van der Merwe, 2014).

In a working paper on teachers, one teacher's response to the question, "Convey your experience as a teacher", was:

Just as a rock climber without the necessary protection ropes will feel, I had a similar feeling regarding my teaching experience at the participating school. We were thrown in at the deep end and we had to climb "for our lives" - it drains me emotionally, it was a total shock, and in the end it was an extremely bad experience. If there are no ropes that you can use to pull yourself up or to ground yourself with, you are going to fall - and it happened to me. Without the support of anybody to help or pull one up, you have to struggle on your own and you have to start climbing from the bottom 
again. I was exhausted and wished that my stay at the school would come to an end. I could not focus on the pupils, neither on my work; my only focus was to survive. I had to use all my power to overcome the circumstances. I missed the whole learning experience because I was personally drained and experienced everything negatively (Jansen \& Van der Merwe, 2014, p. 4).

Previous research clearly states that teachers consistently deal with growing challenges in their working environment such as pupils' problems, a substantial workload, insensitive administrators, the school management, parents' expectations (Ishak, Iskandar, \& Ramli, 2010), discipline problems, and lack of recognition and support (DarlingHammond, 1997).

\section{Education and Teachers in South Africa}

The World Economic Forum ranked the South African education system 133 rd out of 142 countries in the world (ILO News, 2012). The education system failed to achieve basic standards of literacy and numeracy for grade three and grade six. "Poor education lies at the root of most of South Africa's problems, including unemployment, poverty and inequality," it said in a statement by the FW de Klerk Foundation (IOL News, 2012: para. 2)

Two factors that play an important role according to the FW de Klerk Foundation in determining the failure or success of the education system depends on the quality of the principals and the teachers (IOL News, 2012). Ultimately, challenges facing the system is to produce the right kind and number teachers for South Africa. When many skilled teachers leave the profession, it is time to investigate the reason. Perhaps the most critical statistic presented by the National Planning Commission (NPC) is the poor performance of teachers (NPC, 2011). There are teachers in schools who teach an average of only 3,5 hours per day. However, no employee deserves the torture of having to show up for a job that is physically, mentally and emotionally draining.

\section{Human Resource Practice, Perceived Organisational Support and Social Support}

The employment relationship between the parties is seen by the employees as a reciprocal exchange relationship that reflects relative dependence and extends beyond a formal contract. Human resource practice plays an essential role in helping employees form their attitudes and behaviours (Joarder, Sharif, \& Ahmmed, 2011; Meyer \& Smith, 2000).

A critical problem for human resource practice is employees' intention to leave the organisation, as the organisation experiences a loss of talent, and it also brings about the additional costs of recruitment and training (Loi, Hang-Yue, \& Foley, 2006). When employees experience a positive perception of human resource practice, they believe in the social exchange relationship between them and the employer (Joarder, Sharif, \& Ahmmed, 2011; Wayne, Shore \& Liden, 1997; Lee \& Bruvold, 2003).

Embedded in a social exchange theory, greater organisational support is anticipated to result in greater affective attachment to the organisation (Shore \& Wayne, 1993). Organisational support is described as to what extent employees perceive their employer to be concerned with their health and well-being (Grant-Vallonea \& Ensherb, 2001), and how much the employer cares about their employees and values their contribution to the organisation (Allen, Armstrong, Riemenschneider \& Reid, 2008; Eisenberger, Huntington, Hutchison, \& Sowa, 1986). Recent publications mention that school management systems (institutions) need to give institutional/organisational support to teachers by creating career opportunities, promotions, training and development courses and workshops, autonomy, job security and fair labour practices, adequate resources in the classroom and role-modelling (Chiang \& Hsieh, 2012).

Joarder, Sharif and Ahmmed (2011) mention that organisational support theory is a supportive action from supervisors that results in increased positive organisational support. Employees who feel positive, feel more obliged to their employer and repaying the employer by achieving its goals, and also feel more committed, which reduces their intention to leave (Rhoades, Eisenberger, \& Armeli, 2001). Nasurdin, Ramayah and Beng (2008) found that human resource practice have a positive significant effect on perceived organisational support.

Supervisors are seen as agents of the employer. Employees who experience that supervisors social support them and they treated them fairly experience positive organisational support (Eisenberger et al., 1986). However, it was found by Eisenberger, Stinglhamber, Vandenberghe, Sucharski and Rhoades (2002) that a negative relationship exists between supervisory social support and turnover of employees, but studies by Billah (2009) and Abeysekera (2007) did not find any significant relationship between supervisory support and employees' intention to leave the organisation. 


\section{Human Resource Practice and Performance}

Chiang and Hsieh (2012) explains that job performance means that an employee meet job performance expectations and standards, deliver quality work and are effective in their job. A strong relationship are found between human resource practice and performance (Huselid, 1995). Batt and Colvin (2011) explains that in the last two decades theory and evidence on the relationship between human resource practice and performance has expanded significantly, but a lack of research still exists.

Organisational and human resource researchers found that organisational support is a significant predictor of performance. A positive correlations was found by Miao (2011) and Riggle, Edmondson and Hansen (2009) between organisational support and job performance. Chinomona and Sandada (2014) explains that there is still a lack of a conceptual model that show the relationship between organisational support, job satisfaction and performance in the education sector. Amin (2012) found supervisory support are predictors of performance.

According to theory higher expectations are created by extensive performance monitoring systems and this may lead to higher intention to leave rates (Batt \& Colvin, 2011). Research indicate that employees who are high and low performers are more likely to leave the organisations than average performers (Trevor, Gerhart \& Boudreau, 1997).

\section{Purpose of the Study}

The main purpose of this study was to examine the relationship between human resource practice, organisational support, support by supervisors, performance and intention to leave of teachers in South Africa.

\section{Methodology}

\subsection{Sample and procedure}

For the purposes of this study, the researchers followed a quantitative design. Data were collected via a cross-sectional design questionnaire. It was explained to the respondents that this research was voluntary and that the results would be treated with strict confidentiality. Three hundred teachers at different schools were invited to participate in this research. The response rate (i.e. usable questionnaires returned) was $74.46 \%(n=224)$. The characteristics of the participants are shown in Table 1.

Table 1: Characteristics of study population $(n=224)$

\begin{tabular}{|c|c|c|c|}
\hline Item & Category & Frequency & Percentage \\
\hline \multirow[t]{4}{*}{ Gender } & Female (1) & 139 & 62.1 \\
\hline & Male (2) & 76 & 33.9 \\
\hline & Missing values & 9 & 4.0 \\
\hline & Total & 224 & 100.0 \\
\hline \multirow[t]{7}{*}{ Age } & 24 years and younger (1) & 2 & 0.9 \\
\hline & $25-35$ years (2) & 47 & 20.9 \\
\hline & $36-45$ years (3) & 77 & 34.3 \\
\hline & $46-55$ years (4) & 71 & 31.7 \\
\hline & 56 years and older (6) & 17 & 7.5 \\
\hline & Missing values & 10 & 4.5 \\
\hline & Total & 224 & 100.0 \\
\hline \multirow[t]{6}{*}{ Qualification } & Grade 10-2 (1) & 5 & 2.2 \\
\hline & Diploma (2) & 92 & 41.1 \\
\hline & Degree (3) & 51 & 22.8 \\
\hline & Post-graduate degree (4) & 54 & 24.1 \\
\hline & Missing values & 22 & 9.8 \\
\hline & Total & 224 & 100.0 \\
\hline \multirow[t]{7}{*}{ Tenure } & Less than 1 year (1) & 4 & 1.7 \\
\hline & $2-5$ years $(2)$ & 33 & 14.7 \\
\hline & $6-10$ years $(3)$ & 36 & 16.1 \\
\hline & $11-20$ years $(4)$ & 67 & 29.9 \\
\hline & More than 21 years $(5)$ & 77 & 34.0 \\
\hline & Missing values & 7 & 3.1 \\
\hline & Total & 224 & 100.0 \\
\hline
\end{tabular}


The majority of the population was female teachers (62.1\%), with $41.1 \%$ having a diploma. A total of $41.1 \%$ of all the participants had a diploma, while approximately $22.8 \%$ had a degree. Only $1.7 \%$ of the teachers were employed for less than 1 year.

\subsection{Measurement instruments}

\subsubsection{Control variables}

In this research, we controlled for the following variable of teachers: gender (1=female, $2=$ male); age (1=24 years and younger, $2=25-35$ years, $3=36-45$ years, $4=46-55$ years, $6=56$ years and older); qualification (1=Grade 10-12, $2=$ diploma, 3=degree, 4=postgraduate degree), and tenure (1=less than 1 year, $2=2-5$ years, 3=6-10 years, 4=11-20 years, $5=$ more than 21 years).

\subsubsection{Human resource practice scale}

Human resource practice was assessed using Guest and Conway's (2002) eight items. The items focus on employees' experiences over the previous 12 months regarding opportunities to participate, attempts to make the job interesting and varied, training and development, performance appraisal, equal opportunities practice, harassment, and performancerelated pay. The scale reads as follows: 1=yes; $2=$ no, and 3=do not know.

\subsubsection{Perceived organisational support scale}

A short version of the five-items scale of Eisenberger, Fasolo and Davis-LaMastro (1990) was used to measure organisational support. These items are scored on a 7-point Likert scale, ranging from 1 (strongly disagree) to 7 (strongly agree). The items reads as follows: "My organisation really cares about me" and "My organisations strongly considers my goals and values".

\subsubsection{Social support scale}

A five-items scale from Van der Doef and Maes' (1999) measure of social support by supervisor was used. Examples of items are as follows: "My supervisor is helpful in getting my job done" and "My supervisor pays attention to what I am saying".

\subsubsection{Performance scale}

The six-items scale Perceived Performance by Abramis (1994) was used. This is a self-rated scale that reads: "In your own opinion, how well did you fulfil the following tasks?" e.g. "Finish things on time", "Take responsibility" and "Devote yourself to work". A five-point scale was used: $1=$ very badly to $5=$ =very well.

\subsubsection{Intention to leave scale}

Price's (1997) questionnaire was used to measured intention to leave/quit. The questionnaire consists of four items, with a five-point scale (1=strongly disagree to $5=$ strongly agree).

\section{Data Analysis}

SPSS' (2014) version 22 was used to do descriptive and inferential statistical analysis. We furthermore used Cronbach's alpha coefficient and inter-item correlation to determine the validity and reliability of the questionnaires used in this study. Regression analysis was performed to determine the interaction effects between the variables.

\section{Results}

We first examined the descriptive statistics of the questionnaire. As reflected in Table 2, organisational support, social support by supervisors and performance show normal negative distribution scores. Cronbach's alpha coefficient varies between 0.62 to 0.87 . According to Hatcher (1994), a Cronbach's alpha coefficient less that 0.60 is acceptable in the 
social sciences.

Table 2: Mean, standard deviations (SD), skewness, kurtosis and Cronbach's alpha

\begin{tabular}{lccccc}
\hline \multicolumn{1}{c}{ Variable } & Mean & SD & Skewness & Kurtosis & $\alpha$ \\
\hline Human resource practice & 13.91 & 2.55 & 0.12 & -0.06 & 0.62 \\
Organisational support & 9.89 & 2.90 & -0.39 & -0.37 & 0.77 \\
Social Support & 14.70 & 4.23 & -0.82 & 0.01 & 0.87 \\
Performance & 4.19 & 0.53 & -0.62 & 0.78 & 0.84 \\
Intention to leave & 7.54 & 3.83 & 0.37 & -1.05 & 0.81 \\
\hline
\end{tabular}

Pearson correlations in Table 3 show that a positive practical significant relationship with a medium effect exists between human resource practices and perceived organisational support. This is support by Nasurdin, Hemdi and Guat (2008) findings that human resource practice have a positive significant effect on perceived organisational support. We also find a negative and practical significant relationship exists between human resource practices and intention to leave of teachers. Furthermore, a positive practical significant relationship with high effect was found between organisational support and social support by supervisor, but a negative practical significant relationship with a medium effect exists between organisational support and intention to leave.

Table 3: Pearson correlation between human resource practice, organisational support, social support by supervisor, performance and intention to leave

\begin{tabular}{llcccc}
\hline \multicolumn{1}{c}{ Variable } & $\mathbf{1}$ & $\mathbf{2}$ & $\mathbf{3}$ & $\mathbf{4}$ \\
\hline 1. & Human resource practice & 1 & - & - & - \\
2. & Organisational support & $0.32^{* *}$ & 1 & - & - \\
3. & Social support & $0.38^{* *}$ & $0.63^{* *}$ & 1 & - \\
4. & Performance & $0.15^{*}$ & $0.21^{* *}$ & $0.23^{* *}$ & 1 \\
5. & Intention to leave & $-0.35^{* *}$ & $-0.36^{* *}$ & $-0.47^{* *}$ & $-0.21^{* *}$ \\
\hline
\end{tabular}

Stepwise Multiple Regression analysis was performed to see if organisational support, social support by supervisor, performance and intention to quit predict human resource practices. As seen in Model 1, positive organisation support predicts human resource practice for teachers. Model 2 shows that organisational support and social support by supervisor predict positive human resource practices. When adding Model 3 performance it did not show any statistically significant prediction of human resource practices. In Model 4, intention to leave was added. In this model, it is clearly seen that only social support by supervisor predicts positive human resource practices, and intention to leave predicts negative human resource practices. When teachers experience negative human resource practices, they have a greater intention to leave the school or teaching profession.

Table 4: Multiple regression analyses with human resource practice

\begin{tabular}{|c|c|c|c|c|c|c|c|c|c|c|}
\hline \multicolumn{2}{|c|}{ Model } & \multicolumn{2}{|c|}{ Unstandardised coefficients } & \multirow{2}{*}{$\frac{\text { Standardised coefficients }}{\text { Beta }}$} & \multirow[t]{2}{*}{$T$} & \multirow[t]{2}{*}{$p$} & \multirow[t]{2}{*}{$F$} & \multirow[t]{2}{*}{$R$} & \multirow[t]{2}{*}{$R^{2}$} & \multirow[t]{2}{*}{$\Delta R^{2}$} \\
\hline & & B & SE & & & & & & & \\
\hline \multirow[t]{2}{*}{1} & (Constant) & 10.77 & 0.57 & & 19.02 & 0.00 & 33.27 & 0.36 & 0.13 & 0.13 \\
\hline & Organisational support & 0.32 & 0.06 & 0.36 & 5.77 & $0.00^{*}$ & & & & \\
\hline \multirow[t]{3}{*}{2} & (Constant) & 10.10 & 0.60 & & 16.71 & 0.00 & 8.34 & 0.40 & 0.16 & 0.15 \\
\hline & Organisational support & 0.16 & 0.08 & 0.18 & 2.05 & $0.04^{*}$ & & & & \\
\hline & Social support & 0.15 & 0.05 & 0.25 & 2.89 & $0.00^{*}$ & & & & \\
\hline \multirow[t]{4}{*}{3} & (Constant) & 9.43 & 1.28 & & 7.38 & 0.00 & 0.36 & 0.44 & 0.16 & 0.15 \\
\hline & Organisational support & 0.15 & 0.08 & 0.18 & 1.97 & $0.05^{\star}$ & & & & \\
\hline & Social support & 0.15 & 0.05 & 0.25 & 2.81 & $0.01^{*}$ & & & & \\
\hline & Performance & 0.18 & 0.31 & 0.04 & 0.60 & 0.55 & & & & \\
\hline \multirow[t]{5}{*}{4} & (Constant) & 12.51 & 1.68 & & 7.47 & 0.00 & 7.79 & 0.44 & 0.19 & 0.18 \\
\hline & Organisational support & 0.08 & 0.08 & 0.09 & 1.02 & 0.31 & & & & \\
\hline & Social support & 0.13 & 0.05 & 0.22 & 2.51 & $0.01^{*}$ & & & & \\
\hline & Performance & 0.11 & 0.31 & 0.02 & 0.37 & 0.71 & & & & \\
\hline & Intention to leave & -0.64 & 0.23 & -0.20 & -2.79 & $0.01^{*}$ & & & & \\
\hline
\end{tabular}
" $p<0,01$ 


\section{Discussion}

The Department of Basic Education reported that more than four hundred teachers resigned nationally in the first quarter of 2013 alone. Parliament was briefed on the department's performance for the first quarter. The focus persisted largely on department-led objectives that included the expansion of resource materials and national school improvement initiatives - the portfolio committee raised questions about why so many teachers were leaving the profession so early on in the school year (eNews Channel Africa, 2013).

This study explores the phenomena of education decline and the reasons why teachers may be leaving the profession in South Africa. Tables 2-4 integrate the findings of the variables of interest between human resource practice, organisational support, social support by supervisor, performance, and intention to leave concerning teachers in South Africa. The aim of these findings is to integrate all these variables and give a more comprehensive picture of the determinants of supply and demand for teachers in South African schools. Based on the interpretation of these findings, the following recommendations are given to the Department of Basic Education and the relevant parties:

- The Department of Education needs to ensure that effective support structures are established for teachers in order for them to focus on teaching.

- The classroom environment, job security and job satisfaction should be improved. To improve the attractiveness of teaching as a career, specific incentives and initiatives for teachers should be provided.

\section{Conclusion}

The researchers' conclusion from these results is that this study can make a difference in human resource practices, organisational and social support in school management systems, and the knowledge and skills that disappear when teachers leave the school system/classroom due to their negative experiences.

Data in this study suggests that indeed South Africa's quality of education requires a lot of fixing, specifically regarding the relationship between human resource practice, organisational support, social support, performance and intention to leave of teachers.

\section{References}

Abeysekera, R. (2007). The Impact of Human Resource Management Practices on Marketing Executive Turnover of Leasing Companies in Sri Lanka: The Role of Shocks in Employee Turnover. British Journal of Management, 15, 335- 349.

Abramis, D. J. (1994). Relationship of job stressors to job performance: Linear or an inverted-U? Psychological Reports, 75, 547-558.

Allen, M. W., Armstrong, D. J., Riemenschneider, C. K., \& Reid, M.F. (2008). Factors Impacting the Perceived Organizational Support of IT Employees. Information and Management, 45, 8, 556-563.

Amin, S. S. S. (2013). The impact of organisational support for career development and supervisory support on employee performance: An empirical study from Pakistani Academic Sector. European Journal of Business Management, 5(5), 194-207.

Batt, R. \& Colvin, A. J. S. (2011). An Employment Systems Approach to Turnover: Human Resources Practices, Quits, Dismissals, and Performance. Academy of Management Journal, 54(4), 695 - 717.

Billah, M. M. (2009). Human Resource Management Practices and Employee Turnover Intention to Leave: A Study on Commercial Banks in Bangladesh. AMDIB Management Review, 1, 23-42.

Chiang, C., \& Hsieh, T. (2012). The impacts of perceived organizational support and psychological empowerment on job performance: The mediating effects of organizational citizenship behavior. International Journal of Hospitality Management, 31, $180-190$.

Chinomona, R. \& Sandada, M. (2014). Organisational support and its influence on Teachers Job Satisfaction and Job Performance in Limpopo Province of South Africa. Mediterranean Journal of Social Sciences, 5(9), 208-214.

Darling-Hammond, L. (1997). Doing what matters most: Investing in quality teaching. New York: National Commission on Teaching and America's Future.

Eisenberger, R., Fasolo, P., \& Davis-LaMastro, V. (1990). Perceived organizational support and employee diligence, commitment, and innovation. Journal of Applied Psychology, 75: 51-59.

Eisenberger, R., Huntington, R., Hutchison, S., \& Sowa, D. 1986. Perceived organizational support. Journal of Applied Psychology, 71, 500-507.

Eisenberger, R., Stinglhamber, F., Vandenberghe, C., Sucharski, I. L., \& Rhoades, L. (2002). Perceived organisational support: Contributions to perceived organisational support and employee retention. Journal of Applied Psychology, 87(3), 565-573.

eNews Channel Africa. (2013, October, 11). http://www.enca.com/south-africa/teachers-resign-droves

Grant-Vallonea, E. J., \& Ensherb, E. A. (2001). An examination of work and personal life conflict, organizational support, and employee health among international expatriates. International Journal of Intercultural Relations, 25, 261-278.

Guest, D. E. \& Conway, N. (2002). Pressure at work and the psychological contract. London: CIPD.

Hatcher, L. (1994). A step-by-step approach to using the SAS(R) system for factor analysis and structural equation modeling. Cary, NC: SAS Institute. 
Huselid, M. A. (1995). The impact of human resource management practice on turnover, productivity, and corporate financial performance. Academy of Management Journal, 38, 635-672.

IOL News. (2012, August, 2). Our education system is in crisis. Retrieved June 25, 2014 from http://www.iol.co.za/news/south-africa/oureducation-system-is-in-crisis-1.1355362.

Ishak, N. M., Iskandar, I. P., \& Ramli, R. (2010). Emotional intelligence of Malaysian teachers: a comparative study on teachers in daily and residential schools. Procedia Social and Behavioral Sciences, 9, 604-612.

Jansen, C. \& van der Merwe, P. (2014). Narrative report of a teacher about her teaching practice experience. Working paper 1. Department: Educational Leadership and Management. Unisa.

Joarder, M. H. R., Sharif, M. Y., \& Ahmmed, K. (2011). Mediating role of affective commitment in HRM practices and turnover intention relationship: A study in a developing context. Business and Economics Research Journal, 2(4), 135-158.

Lee, C. H. \& Bruvold, N. (2003). Creating value for employees: investment in employee development. International Journal of Human Resource Management, 14, 981-1000.

Loi, R., Hang-Yue, N., \& Foley, S. (2006). Linking employees justice perception to organizational commitment and intention to leave: The mediating role of perceived organizational support. Journal of Occupational and Organizational Psychology, 79(1), 101-120.

Meyer, J. P. \& Smith C. A. (2000). HRM practices and organizational commitment: Test of a mediation model. Canadian Journal of Administrative Sciences, 17(4), 319-331.

Miao, R. T. (2011). Perceived Organisational Support, Job Satisfaction, Task Performance and Organisational Citizenship Behaviour in China. Institute of Behavioural and Applied Management, 1, 1-23.

Nasurdin, A. M., Hemdi, M. A., \& Guat, L. P. (2008). Does perceived organizational support mediate the relationship between human resource management practice and organizational commitment? Asian Academy of Management Journal, 13(1), 15-36.

NPC (National Planning Commission). (2011). National Development Plan. Retrieved June 25, 2014 from http://www.npconline.co.zal medialib/ downloads/home/NPC\%20National\%20Development\%20Plan\%20Vision\%202030\%20-lores.pdf.

Price, J. (1997). Handbook of organizational measurement. International Journal of Manpower, 18, 305-308.

Rhoades, L., Eisenberger, R., \& Armeli, S. (2001). Affective commitment to the organization: The contribution of perceived organizational support. Journal of Applied Psychology, 86, 825-836.

Riggle, R. J., Edmonson, D. R., \& Hansen, J. D. (2009). A meta-analysis of the relationship between perceived organisational support and job outcomes: 20 years of research. Journal of Business Research, 62, 1027-1030.

Shore, L. M. \& Wayne, S. J. (1993). Commitment and employee behavior: Comparison of affective commitment and continuance commitment with perceived organizational support. Journal of Applied Psychology, 78, 774-780.

SPSS. (2014). IBM SPSS Statistics for Windows, Version 22.0. Armonk, NY: IBM Corp.

Trevor, C. O., Gerhart, B., \& Boudreau, J. (1997). Voluntary turnover and job performance: Curvilinearity and the moderating influences of salary growth and promotions. Journal of Applied Psychology, 82, 44-51.

Van der Doef, M. \& Maes, S. (1999). The Job Demand-Control (-Support) model and psychological well-being: A review of 20 years of empirical research. The Job Demand-Control (-Support) model and psychological well-being: A review of 20 years of empirical research. Work and Stress, 13, 87-114.

Wayne, S. J., Shore, L. M., \& Liden, R. C. (1997). Perceived organizational support and leader-member exchange: A social exchange perspective. Academy of Management Journal, 40, 82-111. 